\title{
Liberalismo: 0 Direito e o Avesso
}

\author{
Carlos Estevam Martins
}

\begin{abstract}
hegemonia liberal manifesta-se de diversas maneiras. Uma deA las consiste no fato de que, hoje em dia, tentar ser antiliberal tornou-se tarefa difícil e até mesmo perigosa, capaz de pôr em risco sólidas reputações. Quem não é ou não quer ser liberal, quem tenta combater o liberalismo em nome de alguma concepção alternativa, enfrenta um terreno minado, repleto de armadilhas que induzem ao erro ou expõem os incautos a críticas imerecidas.
\end{abstract}

Suponhamos que você seja um democrata que queira defender a democracia. Se esse for o caso, você tem dois problemas a resolver: um, separar-se do liberalismo, definindo-o como algo que você repudia; dois, conceber a democracia como um ideal distinto, adversamente contraposto ao liberalismo.

Esses dois problemas, no entanto, simplesmente desaparecem se você, juntamente com a maioria das pessoas, pensa que liberalismo e democracia são a mesma coisa ou coisas que se misturam e se confundem, como na expressão "regime liberal-democrático". Neste caso, não há nada a fazer. $\mathrm{O}$ democrata que pensa assim, permita-me dizê-lo, já se acha hegemonizado pelo liberalismo, não o vê como um estranho, como um adversário a ser combatido; ao contrário, admite-o

DADOS - Revista de Ciências Sociais, Rio de Janeiro, Vol. 46, n-4, 2003, pp. 619 a 660. 
como coisa sua, como parte integrante do seu próprio ideário. A democracia, neste caso, perde toda e qualquer especificidade; ela dissolve-se no interior da expressão "liberal-democracia" e é a tal ponto absorvida pelo termo vizinho que, não fosse por sua utilidade para as táticas liberais, poderia ser eliminada sem que de sua exclusão resultasse qualquer prejuízo conceitual. De fato, qual é o plus que um regime soit disant liberal-democrático acrescenta? Que características possui que um regime meramente liberal também não possua?

Nas lutas ideológicas, a indefinição oferece muitas vantagens. Uma delas é ofuscar a visão dos outros. "Não se pode distinguir o regime liberal dos regimes não-liberais", observa José Eduardo Faria (1988), "sem preliminarmente explicitarem-se as ambigüidades que o termo liberalismo costuma expressar na linguagem política corrente". Para Faria, "o liberalismo é hoje uma expressão vaga, ambígua", um conceito "semanticamente desgastado". Diante dessa "imprecisão conceitual", caberia até mesmo perguntar: "haverá alguma possibilidade de se falar em liberalismo no singular, ou seja, unívoco e universal?"

De modo geral, o discurso liberal tem se valido da polissemia para ocultar seus defeitos e exibir qualidades que não possui. O liberalismo tornou-se "um termo confuso e que confunde", observa Immanuel Wallerstein (Folha de S. Paulo, 17/10/1999). Não obstante, "os liberais conseguiram cooptar as oposições: por um lado, os conservadores, que eram contra qualquer tipo de mudança, e, por outro, os radicais que queriam mudanças amplas e rápidas". Hoje, os antigos opositores do liberalismo "podem discutir se querem reformas mais rápidas ou mais lentas mas, basicamente, aceitam as premissas do liberalismo".

Moral da história: quem não é capaz de definir seu adversário não se livra de ser ludibriado e engolido por ele. Quem não distingue, diferencia, delimita, define e demarca não sabe a que se ater e se desnorteia; mesmo que lute, luta a esmo, sem saber contra o que deve lutar, que alianças mobilizar, que compromissos evitar. As questões terminológicas, ao contrário do que se costuma pensar nos meios políticos, nem sempre se reduzem a meras filigranas acadêmicas. Boa prova disso é a pesquisa recém-realizada pela Corporação Latinobarômetro (Folha de S. Paulo, 14/4/2000), que revelou a existência de um alto nível de insatisfação com a democracia por parte dos latino-americanos em geral e dos brasileiros em particular. No nosso caso, apenas $39 \%$ 
dos entrevistados disseram que preferem a democracia a qualquer outro sistema de governo. Os latino-americanos que se dizem satisfeitos com o funcionamento da democracia constituem uma minoria que não passa de $37 \%$ dos entrevistados. Um quadro melancólico, dir-se-ia.

Mas será mesmo verdade que a maioria da população brasileira não aprova nem prefere a democracia? Ou, alternativamente, quem sabe a população simplesmente rejeita o regime liberal que aí está, sem entretanto saber que se trata do regime liberal porque o vê disfarçado de democracia, sob o rótulo liberal-democrático? É difícil saber. Como é possível descobrir o que a população quer ou deixa de querer, quando se desconhece o significado certo das palavras?

\section{A PRÁTICA DA DOUTRINA}

Reconheçamos que é difícil, muito difícil enfrentar o liberalismo. É tão difícil que as maneiras fáceis de enfrentá-lo, embora existam, se revelam inócuas no fim das contas. É o que acontece com as tiradas niilistas, infantilmente radicais. $\mathrm{O}$ famoso subcomandante Marcos, por exemplo, de modo algum, serve à causa da verdade quando diz: "Aqueles que acreditam em esquemas tão rígidos e quadrados como suas cabeças [...] partem da premissa de que o liberalismo é uma doutrina. [...] [Na realidade,] o liberalismo não tem a mínima coerência [...]. Em outras palavras, é pura baboseira teórica" (apud Castells, 1999).

Tampouco se justifica tentar descartar o liberalismo por meio de apodos planfletários - tais como "fascista", "direitista", "conservador", "neoconservador" - que, além de serem inaplicáveis, são injustos. Que sentido tem chamar de "liberal-fascista" a direita que "se apoderou da teologia liberal"? Estas expressões, do referido subcomandante, não servem para nada, a não ser para nos relembrar o antigo partido comunista alemão, que não sabia distinguir a social-democracia do nazismo hitlerista.

O epíteto de "conservador" ou "neoconservador" também não se ajusta ao figurino liberal ${ }^{1}$. Até os dicionários ressaltam que "o liberalismo sempre se apresentou como força dinâmica, não como força dedicada à manutenção dos equilíbrios existentes". Em conexão com isso, vale a pena lembrar a famosa passagem do Manifesto em que 
Marx e Engels assinalam que a época burguesa, com o cortejo de crenças e idéias liberais que a acompanham, se distingue de todas as anteriores por imprimir "uma revolução contínua na produção, uma incessante comoção de todas as condições sociais, um movimento e uma insegurança constantes". Como poderia o pensamento conservador, por mais neoconservador que fosse capaz de se tornar, coadunar-se com semelhante estado de coisas, em que o permanente é justamente a constante mudança? Quem acha que deve chamar os liberais de conservadores precisa antes dizer com que nome pretende designar aqueles verdadeiros conservadores que, por tradição e definição, sempre abominaram o liberalismo. A não ser que, por conservador, entendam o ideário daqueles que, sob a aparência da abertura ao novo, conseguem sacramentar a inalterada permanência das estruturas de dominação e exploração. Tudo bem; mas isso não deixa de ser uma maneira não conservadora de praticar o conservadorismo. Em resumo, talvez se possa dizer que, para os antiliberais, seria muito mais fácil e extremamente mais desafiante deixar de lado as tergiversações e voltar a chamar os liberais simplesmente de liberais, sem sequer o inútil subterfúgio do "neo" à frente do nome que há tanto tempo os designa objetiva, honesta e corretamente.

Por fim, não custa reconhecer que de nada adianta afirmar e até demonstrar, como fizeram tantos críticos de esquerda, que o liberalismo é inaplicável na prática, que é uma concepção antiquada, referida à etapa concorrencial do processo de desenvolvimento capitalista, incompatível com as realidades da sociedade contemporânea, incapaz de fertilizar toda uma vasta gama de possibilidades historicamente constituídas. Nada disso tem grande serventia, pois, entre outras razões, os liberais podem muito bem ganhar o jogo, como vêm ganhando nos últimos trinta anos, sem ser preciso que o fundamentalismo liberal seja posto em prática.

Com efeito, não se deve desconsiderar a hipótese de que a principal utilidade do liberalismo para aqueles que hoje o pregam pode ser apenas de natureza negativa. Talvez o que lhes interesse não seja tanto o bem inalcançável que poderiam fazer a si mesmos, realizando a íntegra de seus próprios ideais, mas muito mais o mal que fazem aos seus oponentes, impedindo-os de avançar na direção de seus próprios objetivos. É de importância secundária saber quanto de liberalismo é capaz de se transformar em realidade, quando comparado com saber quanto de socialismo, democracia, soberania, desenvolvimen- 
to nacional, cidadania republicana, seguridade social, planejamento, intervenção estatal, reformas estruturais, cultura cívica, justiça social, humanismo, desalienação, desenvolvimento pessoal e solidariedade comunitária, quanto de antiliberalismo, enfim, vem sendo abortado na prática, graças à disseminação do "impraticável" ideário liberal.

Quem não se lembra da gloriosa social-democracia européia, que emergiu no cenário político mundial como força notoriamente antiliberal, imbuída do elevado propósito de nos conduzir ao socialismo pela via da plenitude democrática? Ela se propunha avançar impondo sucessivas reformas ao capitalismo mediante o progressivo aprofundamento do planejamento econômico, do dirigismo estatal, do processo de democratização, da transformação das relações capital-trabalho via co-gestão, cooperativismo $e$ Welfare State. Originalmente, cabe lembrar, discutia-se a dicotomia reforma versus revolução. O programa social-democrático era criticado pelas correntes mais radicais por ser gradualista - limitado a avançar aos poucos - e não por ser capitulacionista - empenhado em regressar do socialismo ao capitalismo, da democracia ao liberalismo.

A que ficou reduzida a promessa social-democrata foi o que se viu na última reunião de cúpula da Terceira Via, em novembro de 1999, em Florença. Ali, como anotou Marilena Chauí (Folha de S. Paulo, Caderno Mais, 19/12/1999), falou-se muito em valores: valor da vida, da ética, da família, da liberdade e assim por diante. Mas "a pregação de valores conseguiu a proeza de não falar uma única vez do valor propriamente dito, isto é, do capital e da relação capital-trabalho". Os idealizadores da Terceira Via não se demovem de seus propósitos de "fazer uma economia de centro e uma política de esquerda, ou seja, manter o núcleo duro da materialidade capitalista, acrescido dos valores socialistas: o bolo é o mercado; a cobertura confeitada são os valores socialistas".

Proposta lamentável, certamente. Mas vá lá. O que, entretanto, passa dos limites e alcança as raias do escárnio é a interpretação que se convencionou dar do fiasco social-democrata. Para exemplificar, não precisamos ir muito longe. Aqui está Vicente Barreto, reclamando nas páginas do Jornal do Brasil (27/4/1991) que só "os social-democratas de extração marxista" (isto é, os que não se renderam) não conseguiram captar a grandiosidade das novas feições assumidas pela "soci- 
al-democracia contemporânea, que se libertou de alguns mitos, como a estatização e o nacionalismo [...] e abriu-se para o cosmopolitismo e a economia de mercado". Só aqueles renitentes social-democratas de extração marxista, que "ainda não conseguiram superar o preconceito que identifica no liberalismo a ideologia do Estado burguês", só estes são incapazes de ver que "a social-democracia incorporou e aperfeiçoou as instituições liberais", que essa "absorção da tradição liberal veio sedimentar a convergência entre o liberalismo e o socialismo" e que a configuração daí resultante, "chamada de liberalismo radical por Ralf Dahrendorf", foi teorizada por "socialistas" renomados, como Norberto Bobbio e Felipe Gonzales, que "demonstraram a factibilidade da social-democracia como etapa superior do Estado liberal".

Onde foi parar a especificidade dos social-democratas? Esfarelou-se nas mãos do liberalismo. Quanto mais se aproximaram dos liberais, mais remotos, até se perderem de vista, foram ficando o espírito, os fins, os meios e todos os demais traços característicos de sua identidade. O pior de tudo é que essa mutação histórica, que no passado dava vergonha, se converteu hoje em motivo de júbilo, pois se comemora justamente o oposto do que aconteceu quando se imagina que os social-democratas teriam engolido e superado o liberalismo. A cooptação cega o cooptado. O social-democrata que reconhece a derrota por certo perdeu a batalha, mas, sem ter mudado de opinião, continua lutando por seus ideais; o cooptado, ao contrário, torna-se inofensivo: entrega-se e canta vitória.

Em suma, mesmo que não possa realizar-se positivamente, por ser uma concepção caduca, o liberalismo realiza-se negativamente, impedindo que seus opositores o desbanquem, ao mesmo tempo que os envereda pelos caminhos do autodesvirtuamento.

\section{DEMARCAR PARA SUPERAR}

A reflexão que nos interessa fazer - e que aqui não será apresentada em sua íntegra ${ }^{2}$ - versa sobre o tema geral das relações entre liberalismo e democracia. Dita reflexão começa com a análise dos conteúdos que compõem o núcleo conceitual da concepção liberal, tendo em vista alcançar o objetivo imaginado por José Eduardo Faria, qual seja, o de que se possa "falar do liberalismo no singular, isto é, unívoco e universal". A essa primeira parte, em que se expõe, digamos assim, aqui- 
lo que o liberalismo é, segue-se uma segunda parte em que se faz a análise - aqui parcialmente reproduzida - daquilo que o liberalismo não é, nem nunca será, por estar fora, aquém ou além, de sua natureza. Em outras palavras, trata-se de demarcar (tanto pelo lado do sim, como pelo do não) o círculo que é próprio e exclusivo do liberalismo e dentro do qual ele pode mover-se legitimamente. Com isso, pretende-se resgatar o debate público, expurgando-o das doses de indeterminação, confusão e indecisão propícias à continuidade da hegemonia liberal.

Ambas as démarches - a do ser e a do não ser - derivam sua importância do fato de serem indispensáveis à compreensão da democracia como uma possibilidade à parte, cuja identidade não se confunde com a do liberalismo. O enfrentamento da questão do liberalismo é um passo fundamental para a teorização da democracia como algo distinto, que vale por si mesmo, que não só não depende do liberalismo para existir, como só pode vir a ser se e quando ultrapassá-lo3 ${ }^{3}$.

Mais do que isso, as duas démarches representam incitações a uma rediscussão do liberalismo que ambicione percorrer, metodicamente, as etapas que, segundo Goran Therborn (2000), constituem os momentos fundamentais do pensamento crítico, a saber: primeiro, a análise, portadora de uma revisão inovadora; segundo, a desconstrução, no sentido de "delimitar ou destruir a legitimidade de um sistema"; terceiro, a cartografia dos caminhos de mudança que conduzem a novos modos de ser; por fim, como quarto momento, "a elaboração de mundos alternativos", até certo ponto utopicamente concebidos.

\section{AS FAMÍLIAS DE REGIMES}

Postulemos, como ponto de partida da argumentação que se segue, a tese segundo a qual existem duas grandes famílias de formas de Estado: a família autocrática, à qual pertencem os diferentes regimes de altergoverno, e a família não-autocrática, à qual pertencem os diferentes regimes de autogoverno. Exemplificando, situam-se na família autocrática regimes do tipo Monarquia Absoluta, Ditadura Militar, Sofocracia, Dominação Colonial, Oligarquia, Caudilhismo, Teocracia, Despotismo Oriental, Despotismo Esclarecido (Monarquia Ilustrada), Totalitarismo Fascista ou Stalinista. Do outro lado, na família não-autocrática, situam-se regimes de outra natureza, do tipo Libera- 
lismo, Republicanismo, Anarquismo, Democracia, Sistema Conciliar, Sistema Corporativista, Monarquia Constitucional.

O critério que permite distinguir as duas famílias é o lugar em que está sediado o fundamento da soberania no interior da sociedade estatal. Dada a relação governantes-governados, temos que, no primeiro caso, o poder soberano encontra-se investido na própria pessoa do governante ou no seio de uma instituição específica, que existe em separado, destacada do conjunto dos governados. Por exemplo: Dinastia Real, Forças Armadas, Metrópole, Elite Tecnocientífica, Partido Único, Igreja, Elite Tradicional, Líder Carismático. No caso da outra família, composta pelos regimes não-autocráticos, verifica-se a relação inversa: o fundamento do poder soberano situa-se na pessoa dos próprios governados ou no âmbito de alguma instituição genérica, que não existe em separado, posto que abarca a totalidade dos governados, seja como Povo, Nação ou Corpo Eleitoral, seja como sistema de Federações, Corporações, Conselhos ou Partidos, sistemas organizados e integrados pelos próprios governados, indistintamente e em seu conjunto.

Em resumo, os regimes autocráticos podem ser descritos como absolutistas, e os não-autocráticos, como relativistas. Na vigência dos primeiros, o poder apresenta-se como absoluto, porque se acha concentrado em si mesmo, desembaraçado de vínculos e isento de limites, não admitindo ser subordinado ou sequer contrastado, o que significa dizer que os detentores imediatos do poder estatal o exercem em caráter exclusivo. No caso oposto, dos regimes não-autocráticos, a exclusividade dos governantes é substituída pela dos governados, já que estes são, legal e legitimamente, detentores mediatos do poder estatal e o exercem em última instância, transformando-se assim em relativo o comando conferido por consentimento aos titulares imediatos do poder soberano delegado.

A classificação das formas de Estado em duas grandes famílias é útil por dois motivos. Primeiro, porque cobre a maior parte das figuras históricas do Estado moderno, deixando de fora apenas alguns casos

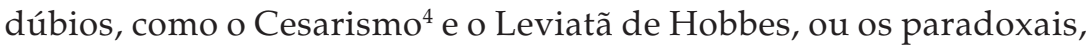
como as Ditaduras Constitucionais em que os governantes se investem de poderes de exceção tão variados e penetrantes que transformam em nulas, vácuas ou insubsistentes as garantias constantes do 
contrato de associação, graças ao qual só aos governados cabe o direito de última palavra.

O segundo motivo que recomenda a classificação das formas de Estado em duas grandes famílias está em que essa providência representa o primeiro passo, o momento inicial do processo de demarcação do liberalismo.

Essa classificação constitui o instrumento com que podemos desmontar um dos pilares sobre o qual se ergue toda a estratégia de enaltecimento do liberalismo. Com efeito, a advocacia liberal opera a partir do princípio, jamais demonstrado, de que todos aqueles que combatem o liberalismo o fazem porque são, de um modo ou de outro, adeptos do autoritarismo. Quem é antiliberal ou meramente não-liberal é automaticamente reduzido à mísera condição de autocrata convicto ou de inocente útil a serviço das causas autocráticas.

Veja-se o livro A Anatomia do Antiliberalismo, de Stephen Holmes, um dos mais ativos militantes liberais da atualidade. Trata-se de um texto escrito para atacar e ridicularizar os inimigos do liberalismo. Mas quem são esses inimigos? Os três primeiros capítulos são dedicados, respectivamente, a Joseph de Maistre, Carl Schmitt e Leo Strauss, três pensadores ostensivamente identificados com doutrinas legitimadoras das formas autocráticas de Estado. Em seguida, vêm os comunitaristas conservadores - Alasdair MacIntyre e Christopher Lasch -, críticos contundentes da sociedade liberal contemporânea, mas refugiados na nostalgia de um passado idealizado, que os impede de propor alternativas não-liberais suscetíveis de se enquadrarem na família dos Estados não-autocráticos. Finalmente, a única exceção na galeria dos autoritários e/ou conservadores antiliberais: o nosso Mangabeira Unger. Exceção apenas aparente, já que Mangabeira, inicialmente apresentado como um antiliberal anarquista e, por conseguinte, inscrito entre os membros da família dos não-autocráticos, acaba sendo redefinido como uma espécie de anarquista arrependido que tentou, mas não conseguiu, deixar de ser um liberal. De fato, na seção ironicamente intitulada "Turning Soft", depois de lembrar que, em seus arroubos de "crítica total", Mangabeira "rotulara as idéias liberais fundamentais de "pot-pourri de platitudes"', Holmes observa que,

“[...] embora flerte com essas posições extremas, ele também se protege. Em algumas passagens, simplesmente revoga suas críticas e adota uma posição indistinguível do liberalismo que, em outros momentos, 
impiedosamente ataca. Essa habilidosa mudança de posições seria um sintoma clássico de antiliberalismo 'soft'".

Com efeito, ainda segundo Holmes, Mangabeira declara "que não é um antiliberal, mas apenas um não-liberal que sempre sustentou 'a inaceitabilidade da doutrina antiliberal pura'". Mas o que significa ser apenas um não-liberal? Para Holmes isso também é inaceitável. “Um não-liberal", diz ele,

"[...] é um antiliberal que, depois de haver desancado o liberalismo em todos os seus aspectos, faz uma surpreendente meia-volta e adota sem hesitar todas as idéias e instituições centrais do liberalismo. Um não-liberal é um antiliberal que não se move além do pensamento liberal. Um não-liberal é, em suma, um antiliberal soft. Depois de ter 'destruído' o liberalismo, ele simplesmente o repete. [...] [Mangabeira] rejeita totalmente o liberalismo, mas também o aceita. Esse ir-e-vir de um lado para outro é a característica essencial do antiliberalismo soft." (Holmes, 1993:155-156)

Conclusão: o debate não se dá com base na suposição de que existem duas grandes famílias de sistemas políticos. Do lado de lá, que é o lado do mal, admite-se que existam várias alternativas autocráticas; mas, do lado de cá, que é o lado do bem, não há alternativas: só existe o liberalismo e nada mais. Quem não é ou não quer ser um liberal não tem escolha: ou é rotulado de autocrático e lançado para o lado de lá, na companhia de Schmitt e de Maistre - quando não de Hitler, Stalin e Salazar -, ou é tratado como um capitulacionista impenitente que ousa o anti enquanto permanece fincado no pró. Se fosse admitida a existência de alternativas não-autocráticas ao liberalismo, qualquer um de nós poderia dizer "sou um antiliberal" sem correr o risco de ser execrado. Mas não! Essa possibilidade está vedada. A "anatomia do antiliberalismo" revela que todo antiliberal é, por isso mesmo, um autocrata, defensor de alguma famigerada modalidade de Estado de exceção. Não se pode sequer optar pela indeterminação e ser apenas um não-liberal, como teria feito Mangabeira Unger. Segundo Holmes, um não-liberal não passa de um antiliberal "who does not mean what he says".

\section{A BOCA DE JACARÉ}

Examinamos até aqui apenas uma das manobras executadas pelo liberalismo para impedir que seus adversários não-autocráticos sejam 
capazes de se auto-afirmar ao mesmo tempo que o demarcam. Trata-se, como vimos, de invasão e plena ocupação do campo não-autocrático, operação que pode ser resumida no slogan "O liberalismo é tudo; fora dele não há nada que preste". Precisamos agora examinar a manobra inversa, de esvaziamento do campo não-autocrático, a operação "boca de jacaré", que pode ser resumida no slogan "Tudo é liberalismo; dentro dele está tudo o que presta". Essa segunda manobra complementa a primeira. Na verdade, para se afirmar como o único ocupante legítimo do campo antiautoritário, não basta que o liberalismo invada esse espaço e escorrace os demais membros de sua família, enxotando-os para os quintos do inferno. Para que essa invasão ilícita ganhe ares de validade e se implante na opinião pública, é preciso que o liberalismo se apresente como bem maior do que de fato é. A melhor maneira de conseguir isto consiste em abrir uma enorme boca de jacaré para engolir e incorporar as virtudes típicas dos demais membros da sua própria família, deixando-os desfalcados de seus títulos de identidade.

É claro que, ao devorar características adversas, traços incompatíveis com sua verdadeira natureza, qualidades que necessita aparentar, mas que não pode digerir e efetivamente assimilar, o liberalismo transforma-se em um monstrengo irreconhecível, repudiado com genuíno horror pelos liberais de alto coturno que dominam o núcleo conceitual da doutrina e fazem questão de se dar ao respeito. Contudo, para a maioria dos militantes liberais que participam das lutas ideológicas no dia-a-dia, essa desfiguração do credo que professam carece de importância: para eles mais vale um liberalismo deformado, porém vitorioso, do que um liberalismo autêntico, porém demarcado e, por conseguinte, sujeito a ser confrontado e, eventualmente, derrotado.

As operações fraudulentas de usurpação das qualidades alheias são ocorrências comezinhas nos escritos liberais. José Guilherme Merquior, em seu livro sobre o liberalismo, diz coisas do seguinte jaez: "O novo liberalismo de 1880 ou 1900 consistiu em três elementos essenciais: ênfase na liberdade positiva, preocupação com a justiça social e desejo de substituir a economia do laisser-faire. Tal grupo de novos objetivos e pressupostos levou a uma nova visão política liberal". No parágrafo seguinte, acrescenta: 
“[...] em contraste, os neoliberalismos triunfantes, cerca de 1980, tinham uma mensagem muito diferente [...]. Tendem a desconfiar da liberdade positiva, julgam a justiça social um conceito desprovido de significação, defendem o retorno ao liberalismo e recomendam um papel mínimo para o Estado. Quanto aos neocontratualistas, alguns deles, como Rawls e Bobbio, estão espiritualmente próximos às inclinações igualitárias do novo liberalismo, enquanto outros, como Nozick, aparentam-se antes com os neoliberais" (Merquior, 1991:218).

Onde, afinal, está o liberalismo? Está no "novo liberalismo de 1880" ou no "neoliberalismo de 1980"? Como será aqui demonstrado em seguida, a resposta é uma só: o liberalismo está lá e cá, está por toda parte, fazendo declarações diametralmente opostas, puxando para o seu regaço teses que lhe são antagônicas, filhas diletas de credos adversários, que ele seqüestra e ostenta como se suas e congênitas fossem.

Até mesmo Roberto Campos por vezes se revolta contra essa falta de demarcação interdoutrinária. Ao prefaciar o livro de Merquior acima mencionado, Campos ataca os chamados "liberais de esquerda", a "tribo mais numerosa da classe política brasileira", formada por aqueles que acreditam na liberdade política, mas admitem intervenções econômicas segundo diversas vertentes: "a vertente assistencialista, a vertente nacionalista, a vertente protecionista e, finalmente, a vertente corporativista, subdividida em três setores: os corporativistas empresariais, os sindicais e os burocráticos. [E arremata]: Esses diversos matizes colorem a fauna abundante dos falsos liberais".

As fraudes sucedem-se impunemente, as contrafações são feitas e não desfeitas, dado que os antiliberais, talvez preferindo não correr o risco de serem taxados de autoritários, deixam tais absurdos passar em brancas nuvens, não se dedicam, como deveriam, ao trabalho diuturno e sistemático de isolar o liberalismo, confinando-o em seus estritos limites e pondo fim às suas constantes incursões em searas alheias. Assim sendo, ninguém tem o direito de se espantar quando esbarra em uma passagem como a seguinte, assinada por Bresser Pereira (Folha de S.Paulo, Caderno Mais, 2/4/2000), que descreve "o caminho da nova centro-esquerda, social-liberal e nacional, que surge na segunda metade dos anos 80 [...] compromissada com as reformas orientadas para o mercado e a reconstrução do Estado". Tal caminho, "do social-liberalismo ou do socialismo liberal", fica-se sabendo, "não seria fácil", posto que é "um caminho do meio [...] sempre ameaçado, à es- 
querda, pelo populismo, e, à direita, pelo globalismo neoliberal". Tirante o fato de que a esquerda, ao ser identificada com o populismo, foi expulsa, como de costume, para o campo dos autoritarismos, pergunta-se: que diabo de liberalismo é esse que se apresenta como nacional-liberalismo, social-liberalismo e socialismo-liberal, sendo que consegue tornar-se tudo isso e o céu também, não só sem deixar de ser liberal, como ainda, de sobejo, se dizendo ameaçado pelo globalismo neoliberal? É ou não é uma fantástica boca de jacaré?

Não se trata de fato isolado, como se pensa em certas rodas acadêmicas, mas de prática generalizada entre os pregoeiros do liberalismo. Isso faz parte da rotina diária de manutenção da hegemonia a qualquer preço. Quem o confessa é o próprio Roberto Campos (O Estado de S. Paulo, 12/4/1992): "Estamos hoje numa idade de ecletismo operacional em que o neoliberalismo absorveu, há longo tempo, as contribuições positivas da esquerda".

É por essas e por outras razões - infinitas outras - que os termos oxímoro e anfótero soam bem quando usados para caracterizar esse liberalismo fingido, que pretende rezar por todas as cartilhas. Oxímoro designa uma reunião de palavras contraditórias como "valentia covarde", "culpa inocente", "filantropo egoísta"; anfótero se diz de uma substância que reúne em si qualidades opostas, reagindo ora como base, ora como ácido. É assim que o liberalismo se comporta. Chamá-lo de oxímoro ou anfótero pode soar como um xingamento, mas é apenas uma descrição.

Nessa noite doutrinária em que todos os gatos são pardos e tudo se mistura, sem rei nem lei, surgem publicações como o livro intitulado Another Liberalism, que bem poderia fazer parte de um seriado tipo Another I, Another II e assim por diante. Da mesma forma, aparecem autores respeitáveis, como Nancy Rosenblum, a declarar, de cara lavada, que "o liberalismo, apoiando-se sobre fundamentos ecléticos, tem apontado sempre na direção da inclusividade", como se o liberalismo, tal qual um Victor Cousin redivivo, tal qual proposta complacente, leviana e enganosa, não tivesse a obrigação moral de se postar como uma concepção de mundo inteiriça, coerentemente estruturada, dotada de identidade própria e inconfundível, capaz de combater com lisura, atacando ou defendendo-se sem abrir mão de sua integridade. 
Vamos agora examinar mais de perto algumas das apropriações indébitas feitas pelo liberalismo. São os seguintes os tópicos a serem abordados: social-liberalismo, liberal-democracia, constitucionalismo, nacionalismo, republicanismo, humanismo e romantismo.

\section{SOCIAL-LIBERALISMO}

Como observou Celso Lafer, em artigo n'O Estado de S. Paulo (10/3/1985) intitulado "Liberalismo, Contratualismo e Pacto Social",

“[...] a visão do assim chamado liberal-socialismo remonta a Stuart Mill e possui importantes expoentes na Itália - como Rosselli e, mais recentemente, Norberto Bobbio. Estes autores, sem renunciar a uma concepção individualista da sociedade, cujo núcleo fundamental é a liberdade, afirmam a indissolubilidade da relação entre liberdade e igualdade. Neste sentido, o liberal-socialismo representa um diálogo construtivo com as correntes de esquerda".

Para Merquior (1991, passim), "o liberalismo social propriamente dito floresceu nos primeiros anos do século XX principalmente graças aos dois Hobs - John Hobson e Leonard Hobhouse". Cometendo uma gritante heresia, Hobson concebia a liberdade como valor substantivo, "o poder positivo de fazer coisas meritórias ou delas usufruir": não apenas a "liberdade de" (negativa), mas também "liberdade para" (positiva). Passando de uma heresia a outra, "via o mercado como ponto de desperdício e desemprego", males contra os quais se teria que recorrer a remédios extra-econômicos. Essa linha de preocupação com a justiça social, ainda segundo Merquior, estende-se até os nossos dias e manifesta-se exemplarmente na rebeldia de Raymond Aron em face da ortodoxia de Friedrich Hayek. A "síntese liberal-democrática" proposta por Aron seria "um amálgama de direitos civis tradicionais com modernos direitos sociais, que ele representa como direitos créditos (droits-créances)". Tal amálgama deixa claro que "a nomocracia de Hayek tem de abrir espaço para as inevitáveis tarefas sociais", o que equivale a dizer que "o governo da lei não pode possivelmente esgotar as funções do Estado".

Outros autores esclarecem que desde sempre o Estado social é apanágio do liberalismo, expresso como princípio na declaração de direitos fundamentais da Constituição girondina, na qual se lê que "os socorros públicos são uma dívida sagrada da sociedade, cabendo à lei de- 
terminar-lhes a extensão e aplicação", preceito este retomado na Constituição francesa de junho de 1793, a qual inclui, entre os deveres da sociedade, "dar a subsistência aos cidadãos infelizes, seja ministrando-lhes o trabalho, seja assegurando os meios de existência àqueles privados da possibilidade de trabalhar" (Bonavides, 1981).

Outros ainda, como John Gray (1988, passim), lembram os "galanteios" que John Stuart Mill dirigia aos "esquemas socialistas" e a ênfase que deu à distinção entre produção e distribuição, de modo a poder sustentar a tese de que "os mecanismos de distribuição estão destinados a ser inteiramente uma questão de opção social". As idéias socializantes de Mill teriam impulsionado o "revisionismo liberal" - a "transição do individualismo para o coletivismo", como diria A. V. Dicey-, dando lugar ao "novo liberalismo", que se distancia do "liberalismo clássico" para abrigar, nas obras de T. H. Green e B. Bosanquet - "inspiradas na filosofia hegeliana" -, a "defesa da atividade e da autoridade governamentais mais intensas e de medidas limitativas da liberdade contratual". Esse movimento reformista desaguaria em O Liberalismo, de L. Hobhouse, "em que os ideais de justiça distributiva e de harmonia social suplantam as velhas concepções de um sistema natural de liberdade".

Ontem, como hoje, sempre se pode colher, como diria Roberto Campos, "uma boa safra de falsos liberais". Segundo Perry Anderson (1989), presenciamos atualmente "uma nova leva bastante significativa de tentativas de sintetizar tradições liberais e socialistas". Anderson anota os últimos trabalhos de C. B. MacPherson, "a estudada ambigüidade" de John Rawls, a mistura de pluralismo político com democracia econômica advogada por Robert Dahl, a renovação da esquerda via ressurreição de Guizot por parte de Pierre Rosanvallon, assim como as obras de David Held, John Dunn, Joshua Cohen, Samuel Bowles e assim por diante.

Nesses casos, como em tantos outros, há que distinguir os fatos da versão dos fatos. Não se pode dizer, levianamente, que o liberalismo mudou a ponto de se transfigurar em um credo socializante só porque meia dúzia de intelectuais mudou de idéia e trocou o liberalismo pelo sincretismo. Em 1848, quando publicou os Princípios da Economia Política, John Stuart Mill descartou as teses socialistas como simples "quimeras". Logo depois, os levantes populares e os confrontos violentos que varreram a Europa comoveram não a doutrina que até então cul- 
tivara, mas Harriet, a mulher que o encantava e sob cuja influência passou a dedicar-se, conforme relata em sua Autobiografia, "ao estudo dos melhores escritores socialistas". A partir daí, sob o duplo influxo dela e deles, "a maior parte do que fora escrito sobre o assunto na primeira edição dos Princípios foi cancelada". De fato, na edição revista de 1849, Mill passou a declarar que a visão dos socialistas seus adversários - não a dos liberais seus correligionários - era "um dos elementos mais valiosos do progresso humano existentes na atualidade" (apud Anderson, 1989).

Conforme nos lembra Perry Anderson, mutações análogas marcaram a carreira intelectual de muitos outros famosos liberais. J. Hobson, liberal até então convicto, mudou de posição ao sofrer o impacto da Primeira Guerra Mundial. Por volta de 1917, podia ser visto como um prócer de esquerda, que atacava a social-democracia por considerá-la insatisfatória, "inadequada à tarefa de derrubar o capitalismo". Com Bertrand Russel passou-se mais ou menos o mesmo. Em 1895, ele escreveu um estudo sobre a social-democracia a partir "do ponto de vista de um liberal ortodoxo", como ele próprio se definia. O programa social-democrata parecia-lhe, então, fadado a "experiências tolas e desastrosas", por não respeitar "as desigualdades naturais". Após a Primeira Guerra Mundial, o homem era outro: propunha agora o socialismo das guildas, que considerava ser - certamente não mais "do ponto de vista de um liberal ortodoxo" - "o melhor sistema exeqüível". Nos Estados Unidos, John Dewey, conhecido como "um liberal resoluto e sem rodeios", impressionou-se, por sua vez, com a Grande Depressão e, tal como seus antecessores, também virou a casaca. Pôs-se a dizer que "a causa do liberalismo estará perdida se não estiver preparada para socializar as forças de produção", devendo valer-se, caso necessário, até mesmo da força para "subjugar e desarmar a minoria recalcitrante". Misturando lembranças de seu antigo credo com os anseios de sua nova persuasão, proclamava: "A economia socializada é a maneira de obter-se o livre desenvolvimento individual".

A Itália tem sido um viveiro particularmente copioso de anfíbios social-liberais. Entre as razões para isso, destaca-se o fascismo, cuja ascensão teve o condão de aliar liberais e socialistas na luta contra o inimigo comum, a ponto até de mesclá-los, como foi o caso do Partito d'Azione - "o partido dos socialistas liberais", no dizer de Bobbio -, que nutria a aspiração de realizar a síntese entre liberalismo e socialismo. Mesmo sem entrar em detalhes, é ilustrativo mencionar a "Re- 
volução Liberal" de Piero Gobetti, intelectual que defendia o livre comércio, ao mesmo tempo que admirava Lenin e colaborava com Gramsci; o "Movimento Liberal Socialista", formado em 1937 por Guido Calogero e Aldo Capitini; o "Socialismo Liberal" de Carlos Rosselli, que, vindo de lá para cá, queria injetar sangue liberal nas veias do socialismo para descontaminá-lo da herança marxista; o "Comunismo Liberal" de Augusto Monti e Silvio Trentin, que defendiam - não se sabe em nome de qual liberalismo - a socialização revolucionária das relações de propriedade.

Por fim, temos Norberto Bobbio, a quem cabe um lugar de destaque nessa galeria sui generis. Figura simpaticíssima, grande scholar sem dúvida alguma, cometeu entretanto dois pecados imperdoáveis. Supercristalino quando analisa o pensamento dos outros, foi, porém, avaro em relação a si mesmo ou não achou imprescindível explicitar, por meio de noções claras e distintas, o conteúdo de sua "idéia fixa", o seu "inicial e nunca abandonado liberalismo" (Bobbio, 1994). Se o tivesse feito, certamente, não teria cometido o seu segundo pecado, que foi misturar aquela idéia fixa com "o ideal socialista", tido inclusive como "superior ao liberalismo". Teria percebido que ceci tuera cela (ou vice-versa) e, por conseguinte, teria chegado, talvez décadas mais cedo, àquela que parece ser a sua conclusão final: "enquanto a conjugação de liberalismo e socialismo foi até agora uma nobre veleidade, a progressiva identificação do liberalismo com o liberismo é um dado de fato indiscutível" (Bobbio, 1988)5.

Agora, uma triste curiosidade. Nos parágrafos anteriores, servi-me fartamente do levantamento feito por Perry Anderson sobre o social-liberalismo. Servi-me dos fatos, não da versão oferecida por Anderson. Isto porque - tamanho é o poder de sedução dos engodos liberais - até mesmo um intelectual do porte de Perry Anderson, detentor de tão vasta erudição e de tanta tarimba acumulada nas lides da esquerda, quando chega a hora de exibir sua própria identidade, não resiste e, voilà, se confessa um liberal. Ainda com a agravante de capitular sem sequer um ressaibo de culpa. Candidamente, Anderson assim abre o seu coração: "Na realidade, sinto com relação ao ideal do liberal-socialismo mais simpatia do que se imagina [...]. A idéia de sintetizar liberalismo e socialismo até hoje não vingou", mas esse "empreendimento" pode ser "retomado com bons resultados". Afinal, "quem iria querer um socialismo não-liberal?" Trata-se de "uma possibilidade" tão desejável que "não vejo de que maneira qualquer 
marxista contemporâneo poderia deixar de saudá-la com fervor" (Anderson, 1989).

O que fazer? Hegemonia é hegemonia. Diga-se apenas - em nome da honra que deve ser prestada ao mérito - que, nesse ponto, Norberto Bobbio sempre teve toda a razão do mundo: como o marxismo nunca se dedicou à elaboração sistemática de uma teoria política propriamente dita, melhor do que ninguém coube-lhe deplorar "a inexistência ou insuficiência ou deficiência ou irrelevância de uma ciência política marxista" (Bobbio, 1983). Mérito de Bobbio, demérito dos marxistas - não de Marx, evidentemente, que, tendo feito tudo o que fez, excedeu de muito o que se pode esperar de um ser pensante, mas dos marxistas, todos eles, convencidos como sempre estiveram, embora não se saiba por que, de que teoria política é coisa desimportante. $\mathrm{O}$ resultado é o que se tem visto.

De modo geral, o que os socializantes pedem aos liberais vai muito além do que eles podem fazer qua liberais. Renato Boschi (1990), por exemplo, convencido de que "a preocupação por excelência do liberalismo é com a delimitação do poder em geral", e não apenas do poder estatal, imagina que o liberalismo, a partir dessa posição mais abrangente, poderia voltar-se contra "a monumental concentração de poder no campo societal" e a "miséria social" daí decorrente.

Acontece, porém, que o liberalismo simplesmente não pode dar esse passo. Primeiro que tudo, porque, para os liberais, "poder societal" não é sinônimo de coerção e, portanto, não tem por que ser limitado, muito menos ainda por restrições decorrentes da intervenção estatal ${ }^{6}$. Este argumento constitui, aliás, a espinha dorsal do livro de Von Mises (1977), onde se lê que o liberalismo não tem por que condenar a concentração e a centralização da riqueza. Os estatistas e os intervencionistas - não os liberais - é que "consideram a propriedade privada ilimitada prejudicial à sociedade". Na verdade, o que contraria "a essência da ordem econômica liberal ideal" seria haver menos riqueza "nas mãos dos particulares do que nas do governo". A mesma tese inspira o repúdio dos liberais à tributação progressiva. Por exemplo: "A redistribuição de renda por meio da tributação progressiva [...] não pode ser reconhecida entre as instituições livres" (J. R. McCulloch, 1830); "A progressividade é uma forma branda de roubo" (John Stuart Mill); trata-se apenas de "discriminação contra os ricos" 
(Hayek); "significa o abandono do sagrado princípio da igualdade perante a lei" (Rudolf von Gneist, 1891) (apud Hayek, 1960a).

Nada indica que os liberais de hoje pretendam incorrer nos mesmos erros cometidos no passado, durante a história primeva do liberalismo, quando ainda se compunham os preâmbulos de um novo modo de pensar o mundo. Os Levellers, por exemplo, teorizando como que avant la lettre, tinham direito ao pensar ingênuo, desatento às contradições que existiam entre a moralidade mercantil do individualismo possessivo, que os atraía por interesse, e a ética social cristã, à qual se apegavam por tradição. Que mal haveria, deviam pensar, em colocar valores menos elevados abaixo dos mais elevados? Os direitos individuais à autopreservação e ao automelhoramento, ainda que importantes, deviam ficar em segundo plano, abaixo do nobre ideal de uma coexistência social humanizada, alçada ao posto de "soberano bem supremo da humanidade", junto com o cortejo de obrigações, que a todos incumbem, de trabalhar para a "felicidade comunitária" (conforme MacPherson, 1962).

Confusões desse quilate se tornaram inadmissíveis, até para aqueles que, como Bobbio, alguma vez as fizeram. De fato, em inúmeras oportunidades, Bobbio deslinda essa confusão colocando, de um lado, os princípios de igualdade vinculados ao surgimento do Estado liberal, e de outro, o assim chamado igualitarismo democrático, referido ao ideal de uma certa equalização econômica, estranho ao pensamento liberal. Em Liberalismo e Democracia, ele lembra que "mesmo diante do contraste entre duas ideologias nascidas em contraposição uma à outra e, nas suas linhas programáticas, antitéticas, como liberalismo e socialismo, existiram tentativas de mediação ou de síntese" (Bobbio, 1988:86). A despeito de tais tentativas, entretanto, prevaleceu a força do óbvio: "A antítese, porém, permaneceu e se foi reforçando e enrijecendo nos dois últimos decênios", não só como reação "[ao] flagrante não-liberalismo dos regimes" implantados nas sociedades chamadas socialistas, como também em face da "emergência de aspectos não-liberais nos regimes em que mais avançou a realização do Estado-previdência" (ibidem). Não há o que fazer: "liberdade e igualdade são valores antitéticos, no sentido de que não se pode realizar plenamente um sem limitar fortemente o outro: uma sociedade liberal-liberista é inevitavelmente não-igualitária, assim como uma sociedade igualitária é inevitavelmente não-liberal" (idem:39). De forma igualmente taxativa, Bobbio afirma que "o Estado liberal se contra- 
põe tanto ao Estado absoluto quanto ao Estado que hoje chamamos de social" (idem). A ilação que daí decorre é clara como água: como nada no mundo pode ser tão antiliberal quanto o Estado absoluto, vê-se que o Estado social, situado no mesmo plano, é encarado - acertadamente, deve-se acrescentar - como um fenômeno abominável.

Ao assumir tais posições, Bobbio filia-se a uma ilustre tradição, na companhia de Locke, em uma ponta, e Hayek, na outra. Já dizia Locke que a apropriação privada efetuada por uns aumenta a riqueza deixada aos demais. Quando, por exemplo, devido ao avanço da apropriação fundiária, não sobra mais terra para os outros, estes últimos também saem ganhando, porque passam a usufruir de um padrão de vida superior e melhor, que não existiria não fosse a apropriação previamente ocorrida.

Ao longo dos séculos, tais convicções permaneceram inabaladas. Como mostra Richard Bellamy (1994), "a crença de que o sistema econômico pudesse normalmente assegurar empregos e salários de subsistência a todos que estivessem dispostos a trabalhar", crença que transformava "a miséria em resultado da depravação e da imprevidência dos próprios indivíduos", forneceu a justificativa racional para "a abordagem liberal do problema social nas décadas de 1860 e 1870". Assim, por considerar que uma sociedade de mercado livre, controlada apenas pelo império da lei, garante a todos oportunidades iguais de prosperidade, François Guizot, inspirando-se na mais pura tradição liberal, "opunha-se firmemente à redistribuição da riqueza pelo Estado" e declarava que isso "abolia a responsabilidade inerente à liberdade humana e despertava paixões negativas por meio de falsas esperanças" (apud Bellamy, 1994).

O próprio T. H. Green, em geral saudado como um dos inspiradores do social-liberalismo, não deixou de criticar as leis de promoção social, "que limitam o desenvolvimento das disposições morais dos indivíduos". Tais leis, embora partissem do espírito de generosidade, incorriam no inconveniente de "limitar o espaço para a auto-imposição de deveres e para a manifestação de motivações altruístas" por parte de terceiros (idem).

Note-se que esse tipo de argumentação, embora fosse proveitosamente usado por porta-vozes do conservadorismo, possui um inconfundível matiz liberal, dado que o raciocínio em questão só faz pleno 
sentido para quem tem em mente indivíduos abstratamente considerados e não categorias sociais específicas, mergulhadas nos círculos viciosos da miséria. Presume-se que, por natureza, os indivíduos são igualmente capazes de guiar a si mesmos na luta pela vida. "Se os homens", observa MacPherson (1962), "são igualmente racionais, no sentido de igualmente capazes de cuidar de si mesmos, aqueles que ficaram permanentemente para trás na caça à propriedade só podem queixar-se de si mesmos". Essa presunção antipaternalista da igual maioridade de todos é necessária e suficiente para reconciliar "a justiça do mercado com as noções tradicionais de justiça comutativa e distributiva".

Para um liberal de verdade, a pobreza (seja ela material ou espiritual) decorre dos acasos, bons ou ruins, e das opções livremente feitas por cada indivíduo ao longo de sua existência. Há os que preferem o enriquecimento material ou o desenvolvimento espiritual e vão atrás disso. Outros preferem outras coisas, da ascese à devassidão. Pouco importa. São decisões pessoais, de foro íntimo, que a ninguém mais dizem respeito. Quem se intromete se arrisca a ouvir: mind your own business! O compromisso liberal reporta-se apenas à criação e à preservação das precondições institucionais que garantem o livre exercício das escolhas pessoais. Dada a ambientação adequada, daí para a frente o que conta é que cada indivíduo detém a propriedade natural de suas próprias capacidades e, por extensão, de sua própria pessoa, sem nada dever a ninguém por isso e sem que nada mais lhe seja devido por quem quer que seja.

Os nossos liberais não ficam atrás dos estrangeiros. Roque Spencer de Barros (1971), saudado a justo título como uma das figuras de proa do liberalismo brasileiro, baseia-se na noção de uma ordem natural, que surge espontaneamente a partir da interação dos indivíduos livres, para estabelecer que existe "um cosmo econômico, um sistema de leis naturais que descansa em si mesmo, independentemente das opiniões dos homens". Conclui-se daí que "as indébitas intervenções humanas", que contrariam essa ordem natural, não passam de "desastrosas intromissões", "de antemão condenadas ao malogro".

Spencer de Barros rememora a agenda do colóquio Walter Lippmann (Paris, 1938), no qual se celebrou a "aurora de um novo liberalismo", que incluía o atendimento de "fins sociais" e admitia que para esse propósito "uma parte da renda nacional pudesse ser subtraída ao 
consumo". Contudo, as boas intenções quanto ao social batem de frente com as firmes convicções quanto à economia e à política. Esse novo liberalismo autocontraditório teria de ser, conforme reconhece o próprio Spencer de Barros, "algo muito menos radical do que aquilo que Keynes proporia". De fato, é-lhe insuportável admitir o veredicto keynesiano: "Os dois principais defeitos do mundo econômico em que vivemos são a sua incapacidade para garantir o pleno emprego e a sua arbitrária e desigual distribuição da riqueza e dos rendimentos" (Keynes apud Spencer de Barros, 1971). A premissa keynesiana mostra-se tão inadmissível quanto a conclusão que ela enseja: “a existência de órgãos centrais de direção, necessários para alcançarmos o pleno emprego (e combater os demais 'defeitos do mundo econômico em que vivemos'), implica, naturalmente, uma grande extensão das funções tradicionais do governo". Para qualquer liberal bem formado-e Roque Spencer de Barros era um deles - isso é demais.

A voz de Hayek soa em uníssono com tudo quanto se disse até aqui. O ponto de partida de sua argumentação é o mesmo que o de Spencer de Barros: a existência de uma ordem espontânea e policêntrica que ele chama de catalaxia. Dada a magnitude de nossa ignorância, diz Hayek (1960a passim), "o avanço da civilização depende de ser concedida a máxima oportunidade para a ocorrência de acidentes". Como os acidentes favoráveis não ocorrem com certeza - são apenas prováveis -, o funcionamento de uma ordem natural espontânea "envolve riscos deliberadamente assumidos, o possível infortúnio de indivíduos ou grupos, [...] a possibilidade de sérios fracassos ou mesmo involuções que afetam a maioria". Quem opta pelo policentrismo tem que estar preparado para conviver com a instabilidade e a desigualdade das condições de vida, pois seria de todo contraditório para um policentrista endossar as medidas de combate aos males sociais propostas pelos diferentes tipos de monocentrismo, de direita ou de esquerda.

A insegurança quanto ao futuro e as diferenças para melhor ou para pior são conseqüências inevitáveis da liberdade individual assegurada pelo policentrismo. A igualdade perante a lei

“[...] é a única espécie de igualdade que podemos garantir sem destruir a liberdade. Não somente a liberdade nada tem a ver com outras espécies de igualdade, como ela própria produz desigualdades de vários tipos. Isso, inclusive, faz parte da justificação da liberdade indivi- 
dual [...]. Se as diferenças não tivessem importância, a liberdade também não teria importância" (Hayek, 1960a).

É fundamental partir de uma compreensão correta a respeito do modo como funcionam "as forças que tornaram possíveis a Grande Sociedade e a civilização" (Hayek, 1985). É por não serem capazes de alcançar essa compreensão que são falsas "todas as doutrinas totalitárias, das quais o socialismo é apenas a mais influente". A distribuição de benefícios e ônus pelo mecanismo do mercado só poderia ser considerada injusta "se resultasse de uma alocação deliberada a pessoas específicas". Mas não é assim que a ordem policêntrica funciona: as cotas que cada um obtém resultam de "um processo cujo efeito sobre pessoas específicas não foi pretendido, nem previsto por ninguém".

Hayek retoma a concepção, de origem lockiana, assim formulada por J. W. Chapman: "só o modo como a concorrência é realizada, não os seus resultados, é que pode ser justo ou injusto" (apud Hayek, 1960a). Para ele, não há nenhum conceito de justiça que permita classificar de injusta a distribuição de renda e de riqueza "resultante do funcionamento de um sistema justo". O mesmo, segundo Hayek, é afirmado por John Rawls, que relega, como "errônea em princípio", a pretensão de classificar como justa ou injusta essa ou aquela forma específica de distribuição de coisas desejadas: "o sistema de instituições é que deve ser julgado e julgado de um ponto de vista geral" (Rawls apud Hayek, 1960a). Quando e onde ocorrem, "pobreza e infortúnio são males, não injustiças", diria H. B. Acton (apud Hayek, 1960a), descrevendo a "moralidade do mercado". É preciso entender que não vivemos no melhor dos mundos, mas apenas no melhor dos mundos possíveis. Para educar os jovens, recomenda Hayek (1985) realisticamente, "deveríamos enfatizar que, inevitavelmente, alguns indivíduos terão sucesso, embora não o mereçam, enquanto outros fracassarão, embora merecessem o sucesso" 7 . O que os indivíduos reconhecem uns nos outros é o valor que cada um representa para os demais, não o mérito que eventualmente possam ter. E o valor, "a utilidade social relativa das diferentes atividades", é o resultado de eventos que não podem ser previstos ou controlados.

Indiferentes a essa ordem de reflexões, "os precursores do socialismo" - e não os liberais - "desde o começo da Revolução Francesa" passaram a reivindicar "egalité de fait em lugar de egalité de droit". De lá para cá, a expressão justiça social, que traduz "as aspirações que 
constituem a essência do socialismo", foi ganhando divulgação e prestígio crescentes, a ponto de transbordar o campo socialista e ser adotada por outros movimentos,

“[...] em particular pelo clero de todas as tendências do cristianismo [as quais] à medida que perderam a fé [...] foram buscar refúgio numa nova religião social [...] para prosseguir em sua missão de fazer o bem: a dedicação à causa da 'justiça social' tornou-se o principal meio de expressão da emoção moral, o atributo distintivo do homem bom".

Hayek não admite que o liberalismo seja confundido com essas tendências que significam a sua negação. Os ideais de justiça social devem ser repudiados porque constituem "um atavismo, uma vã tentativa de impor à Sociedade Aberta a moral da sociedade tribal". Isso representa "franca ameaça à sobrevivência da humanidade", cujo avanço histórico só foi possível graças à existência da ordem policêntrica de mercado.

Os ideais de justiça social ignoram as condições requeridas por aquela ordem e as desrespeitam. Desconhecem que "levar em conta as desigualdades de fato que existem entre os indivíduos e usá-las como desculpa para exercer coerção discriminadora constitui violação dos termos básicos em que homens livres aceitam submeter-se ao governo". Trata-se, portanto, de pecado capital, que afronta a viga mestra do credo liberal. Além dessa razão de fundo, é preciso compreender que, tendo a ver com o conteúdo material da vontade, o bem-estar, como dizia Kant, "carece de princípio": "para uns consiste nisso; para outros, naquilo". Seu atendimento é por natureza particularista e, por isso mesmo, suscita a continuada renovação das intervenções governamentais arbitrárias, que transgridem o pacto liberal e o nulificam.

Hayek combate a noção de justiça social com a repulsa e a indignação dos que se lançam em uma guerra santa. Para ele, "a crença reinante na justiça social é provavelmente a mais grave ameaça à maioria dos valores de uma civilização livre". A expressão justiça social "não pertence à categoria do erro, mas à do absurdo, como a expressão uma 'pedra moral'". As pessoas que a empregam "simplesmente não sabem o que de fato estão dizendo". Trata-se de uma expressão "totalmente desprovida de significado ou conteúdo" em uma sociedade de indivíduos livres. Para dar-lhe significado, seria preciso efetuar "uma completa mudança do próprio caráter da ordem social, com o 
sacrifício dos valores que a motivam [...] e a destruição do único clima em que a liberdade individual pode florescer".

No auge de sua indignação, Hayek chega a afirmar que a expressão justiça social é "uma insinuação desonesta". E acrescenta: "Do ponto de vista intelectual a expressão é desonrosa, símbolo de demagogia ou jornalismo barato, que pensadores responsáveis deviam envergonhar-se de usar".

$\mathrm{Na}$ área do direito, é igualmente evidente a contraditoriedade entre a questão social e a idéia liberal. Para os cultores das letras jurídicas treinados na ótica liberal, a recepção do Estado social exigiu um tour de force que demandava habilidades de contorcionista da parte daqueles que, como Ernst Forsthoff (1973), tentaram acertar contas com aquela intratável novidade que ameaçava metamorfosear a natureza do Estado liberal.

O Estado social acarreta o fenômeno de juridificação que Max Weber descreveu como "materialização do direito formal". Nada menos que um abalo crucial é o que se verifica quando o direito passa a ser utilizado como simples meio para validar a consecução dos objetivos particulares de um aparelho estatal empenhado em direcionar, redistribuir, equilibrar, promover, estabilizar ou reformar as engrenagens da vida social e os resultados espontaneamente obtidos pelas relações de interdependência geral. Como foi frisado por Jürgen Habermas (1992), na esteira do amplo e continuado debate suscitado por essa questão no campo dos estudos jurídicos, "modificam-se as funções e a estrutura interna do sistema jurídico" e "a própria forma do direito se transforma a partir dos imperativos desse novo tipo de utilização das normas legais". Segundo Habermas, Weber atribuía ao avanço dos modernos problemas de classe a introdução no direito de "aspirações materiais que reivindicam a necessidade de um direito social fundado em postulados éticos de entonação patética, tipo 'justiça' ou 'dignidade humana'". Tal novidade, contudo, "põe radicalmente em questão o próprio formalismo jurídico".

É com essa mesma crítica que Hayek ataca a Declaração Universal dos Direitos Humanos. "Esse documento", diz ele, "é uma tentativa de fundir os direitos da tradição liberal com uma concepção completamente diversa, oriunda da revolução marxista russa". Falar de direitos quando o que está em jogo "não passa de aspirações" é algo que 
“adultera a palavra 'direito', cujo significado estrito é importantíssimo preservar". Em suma, "os consagrados direitos civis e os novos direitos sociais e econômicos são, na realidade, incompatíveis; esses novos direitos não podem ser aplicados sem que se destrua, ao mesmo tempo, a ordem liberal colimada pelos direitos civis".

Por aí se compreende a dificuldade com que Forsthoff se debateu. Com razão, ele não podia admitir justamente aquilo que a Constituição alemã autorizava, a saber, que o princípio do Estado social compartilhasse o mesmo plano em que se situam os princípios constitucionais liberais ou que viesse a incidir na construção formal do Estado de direito, infringindo a lógica baseada na forma abstrata e universal da lei. Por certo, um Estado que passa a atuar, nas palavras de Habermas, como "parte diligente, intervindo ativamente na estrutura social com prestações administrativas de tipo planejador e assistencial, acaba deformando o Estado de direito" tal como o liberalismo o concebe.

Aqueles que, como Forsthoff, contestam a igualdade hierárquica entre a noção do Estado social e o princípio formal do Estado de direito têm que fazer, pelo menos, o que ele fez: repudiar a promiscuidade, retirando o Estado social do plano constitucional para rebaixá-lo ao nível inferior da legislação ordinária.

Por outro lado, o também insatisfatório positivismo democrático advogado por Wolfgang Abendroth, indo no sentido oposto ao de Forsthoff - salvar a criança recém-nascida (o Estado social) e jogar fora a velha água do banho (o Estado liberal) -, serve para patentear, em sentido inverso, a incompatibilidade entre os dois princípios que compõem o social-liberalismo. Reconhecendo que o "direito" apropriado ao Estado social é um corpo estranho, refugado pelo ordenamento jurídico liberal, o positivismo democrático agarra-se a Rousseau e dá um salto no escuro, erigindo a autodeterminação popular - "o processo de formação da vontade do povo entendido como totalidade" - em princípio único do qual flui o ordenamento da vida social, não importa com que conteúdos ou com quais graus de coerência e certeza. Nessas condições, a juridificação torna-se praticamente total: "A forma do direito", como diz Habermas (1992), "serve apenas para traduzir os programas de reforma em decisões obrigatórias. $\mathrm{O}$ direito deixa de possuir uma estrutura intrínseca, suscetível de vir a ser objeto de distorção". 
Antes de encerrar esta seção, cumpre esclarecer que nada do que foi dito aqui se contrapõe a propostas assistenciais, como o programa de renda mínima, aventado por Milton Friedman, ou, mais remotamente, "o direito natural à vida", antanho reivindicado pelos Levellers. Friedman, por exemplo, não tem a intenção de fazer justiça em nome do ideal de igualdade substantiva. Ao contrário, sua proposta é autenticamente liberal porque nada tem a ver com caridade, comiseração ou qualquer outro propósito altruísta, coletivista ou socialista. $\mathrm{Na}$ verdade, ela é tão genuinamente liberal que parece brotar, cristalina, das páginas em que Locke enfrenta e equaciona, em termos estritamente liberais, o problema da pobreza absoluta. Segundo Locke,

“Deus não deixou um único homem à mercê de outro de modo que este pudesse fazê-lo morrer de fome se assim o desejasse. [...] [Cada indivíduo] tem direito àquela porção da abundância de outrem que possa afastá-lo da extrema necessidade [...]. É tão injusto que alguém faça uso da necessidade de outrem para forçá-lo a converter-se em seu vassalo quanto um homem mais forte dominar um mais fraco, obrigá-lo a obedecê-lo e, com um punhal no pescoço, fazer com que escolha entre a morte e a escravidão" (Locke, 1998:244).

Essa maneira de pensar é corretamente liberal, não porque Locke o disse - nada de magister dixit -, mas porque se trata de proposição diretamente deduzida daquele valor lídimo, inquestionável e inegociável que é bem supremo: a liberdade individual. É a preservação da liberdade que autoriza o poder público a tirar de uns para dar a outros. Note-se, no entanto, que para ser livre ninguém necessita de maiores luxos: basta respirar, comer, mover-se. Por conseguinte, o direito à liberdade fundamenta e, ao mesmo tempo, limita o alcance das ajudas assistenciais, reduzindo-as às dimensões de uma singela prodigalidade: trata-se antes de evitar que a fome mate que matar a fome até saciar o faminto.

Isto é liberal porque tem fundamento liberal. Ao contrário, não são liberais certas asserções aterrorizantes, procedentes do pseudoliberalismo, como é o caso do juízo de Deus, proclamado por Herbert Spencer: "Os que são capazes de viver, viverão e é justo que vivam; os que não são capazes de viver, morrerão e é justo que morram". Ou então a máxima de Nozick: "De cada um segundo o que escolhe fazer; a cada um segundo o que faz para si mesmo". Darwinismo e liberismo não são liberalismo. 


\section{LIBERAL-DEMOCRACIA}

Assim como liberal não combina com social, também não combina com democracia. Toda gente fala em liberal-democracia, só que não faltam autores liberais, como Gerhard Ritter (1972), para quem "o Estado democrático e popular é o mais ilimitado dos déspotas", razão pela qual "desde o começo existiu uma inimizade mortal entre liberalismo autêntico e a autêntica democracia". Kant disse o mesmo em $A$ Paz Eterna: "segundo o apropriado entendimento do termo", a democracia constitui "necessariamente um despotismo".

Na perspectiva do desenvolvimento da democracia, o cenário é idêntico. Para Norbert Lechner (1982), por exemplo, o caso do Chile ilustra bem o fato de que "o projeto neoliberal é uma reação a 1789 enquanto nascimento da soberania popular e do Estado democrático. Mais que oposição a um determinado governo, no caso o de Allende, trata-se de repúdio a toda a história da democracia".

Com efeito, como é possível ser um democrata sem acreditar que podemos criar, deliberadamente, o futuro da humanidade? Inversamente, como é possível ser um liberal e não condenar "a ilusão de que podemos criar, deliberadamente, o futuro da humanidade"? Aquilo que para o democrata é artigo de fé, para o liberal é pecado capital. São concepções distintas. Não há o que fazer, muito menos o que misturar: a chamada liberal-democracia não é uma síntese bem-sucedida da genética institucional. É apenas uma maneira de promover as vendas do liberalismo no mercado ideológico, ao mesmo tempo que se impede a democracia de prosperar. É um truque.

Certos liberais do tipo consciencioso, como Sérgio Rouanet, reconhecem a existência de caminhos divergentes:

"É verdade que a Ilustração se preocupa mais com a implantação de estruturas liberais - o uso e o exercício do poder dentro de limites compatíveis com a autonomia do indivíduo - que com a implantação de estruturas democráticas - a geração do poder pela ação autodeterminada dos cidadãos. Ela tem mais horror ao despotismo que entusiasmo pela soberania popular" (Rouanet, 1993:131).

Outros liberais, do tipo tripudiador, como Paulo Francis, falam despudoradamente: "É necessário separar as coisas. A idéia de democracia não me interessa. Eu gosto é de liberdade. Não quero ser preso 
porque dei uma opinião. Liberdade não tem nada a ver com eleições" (Francis, 1994).

Na verdade, Francis está certo: é preciso separar as coisas. Mas como fazê-lo? Essa é a grande dificuldade que os democratas precisam enfrentar, se quiserem se tornar capazes de saber do que estão falando quando se referem à democracia.

As dificuldades começam no seguinte ponto, de capital importância: há uma série de itens que, embora sejam geralmente atribuídos à democracia de forma exclusiva, na realidade também são próprios do liberalismo. Exemplos:

- Instituições representativas, regidas por uma Constituição, formando um sistema de autogoverno ou governo por consentimento.

- Sistema eleitoral com direito a voto igualitário (cada cidadão, um voto), eleições periódicas, sufrágio universal.

- Movimentos sociais, campanhas reivindicativas, manifestações de protesto, propaganda e agitação político-ideológica.

- Competição entre os candidatos a postos eletivos, decisões tomadas com base no princípio majoritário, alternância no poder por meios incruentos.

- Direito de oposição e ao uso público da razão.

À primeira vista, quem lê essa relação de tópicos tem a impressão de que se trata de uma descrição do regime democrático. De fato, em parte é isso mesmo. O problema está em que também se trata, em parte, de uma descrição do regime liberal. Todos esses traços fazem parte tanto da democracia quanto do liberalismo. Eles constituem elementos comuns, situados na interseção de dois conjuntos distintos que, embora compartilhem o mesmo subconjunto de características, são e permanecem antagônicos entre si. Obviamente, isso torna fácil confundir um com o outro e difícil separar um do outro.

Para avançar na compreensão desse ponto, analisemos os casos do princípio majoritário e do sufrágio universal. É sabido que esses dois preceitos só muito tardiamente foram incorporados à prática dos liberais. Desde os seus primórdios, sempre existiu na tradição liberal uma incômoda contradição entre a insistência na santidade da propriedade privada e a adoção da regra majoritária cum sufrágio universal, preceitos estes que, não obstante, desde sempre estiveram ins- 
critos no seio do ideário liberal. Nos primeiros tempos, temendo as maiorias eleitorais inevitavelmente formadas pelos destituídos e demonstrando mais apego às suas propriedades do que aos seus princípios, os liberais optaram por sistemas eleitorais de sufrágio restrito, tipo voto censitário e/ ou qualificado. Adotaram, portanto, uma saída pragmática: dado um corpo eleitoral limitado, exclusivamente formado por proprietários e congêneres, qualquer maioria haveria de ser sempre uma boa maioria.

Outros tempos, novos costumes. De lá para cá, diversos estratagemas foram adotados para neutralizar a força supostamente ameaçadora da regra majoritária quando combinada com a ampliação do sufrágio. Os liberais continuaram se adaptando pragmaticamente e, verdade seja dita, escreveram ao longo desse processo uma admirável história repleta de sucessivos êxitos, hoje em dia coroada pelo fato de serem liberais praticamente todos os regimes não-autocráticos existentes. $\mathrm{O}$ liberalismo, vitorioso, tornou-se merecidamente hegemônico em plena vigência do sufrágio universal, do princípio majoritário e de todos os demais itens constantes do cardápio, simultaneamente liberal e democrático, acima apresentado. Para tanto, bastou-lhe ir se adaptando às características de cada época. Não foi necessário mudar uma única vírgula de seu ideário básico, uma vez que não há praticamente nada no status quo que seja incompatível com as premissas fundamentais do liberalismo.

O triste é que os defensores da democracia não compreendem isso, não aceitam isso, não querem ouvir falar disso. É lógico. Não existe coisa mais fácil do que dizer: não sou um simples liberal; sou um democrata, porque defendo o sufrágio universal, o princípio majoritário e tudo o mais que se acha naquela lista. É fácil, mas não quer dizer nada: qualquer simples liberal pode dizer o mesmo, tranqüilamente.

É claro que as chamadas "conquistas democráticas" resultaram, em grande parte, do empenho e das pressões exercidas pelas forças populares. Mas e daí? Os liberais tiveram apenas que se adaptar e pronto: incorporaram aquelas "conquistas" e as implementaram a seu modo. Não tiveram que mudar de idéia. Mudaram apenas de estratagema e, graças aos novos e sofisticados truques que foram inventando, continuaram inviabilizando, magistral e vitoriosamente como sempre, a instauração do Estado especificamente democrático. 
Dadas as condições históricas reinantes em sua época, Locke podia se dar ao luxo de excluir os não-proprietários do processo eleitoral. Mas isso tem a ver com Locke e sua época, não com o liberalismo. Ou seja, não faz parte do credo liberal o comprometimento com qualquer sistema que restrinja o direito de voto por critérios particularistas, como posses, renda, ocupação, qualificação, raça, classe, gênero, alfabetização, fé religiosa ou opção político-ideológica. Que pedaço do liberalismo pode ser contra a igualdade de todos perante a lei? Nenhum.

Assim sendo, compete aos publicistas democráticos deixar de lado as facilidades e ir atrás de outras razões - necessariamente não simplistas, nem simplórias - que, de fato, permitam distinguir a democracia do liberalismo e estabeleçam o que especificamente pertence a um e não ao outro, assim como a lista dos predicados comuns a toda e qualquer ordem social não-autocrática.

Um belo passo nessa direção é tomar consciência de que os liberais, mesmo ao se dizerem liberal-democratas, classificam os democratas como adversários e conseqüentemente os combatem, às vezes de forma aberta, quase sempre, porém, de modos sutis que se disfarçam sob as mais diferentes camuflagens.

No léxico liberal, democracia significa uma concepção potencialmente absolutista, à qual é inerente o perigo do despotismo, do monismo, do totalitarismo, da tirania da maioria. Vale dizer, a democracia é tendencialmente desviada para o lado de lá e colocada sob a suspeita de ser filiada à família dos regimes autocráticos.

Para Bobbio (1988),

“[...] a tradição autêntica do liberalismo não pode deixar de acertar as contas com a tradição do pensamento democrático, não apenas no que diz respeito à democracia igualitária (substantiva), que mal se concilia com o espírito do liberalismo, mas quanto à própria democracia formal, cujo exercício levaria por toda parte a um excesso de intervencionismo, incompatível com o ideal de Estado que governe o menos possível".

"Democracia e liberalismo", diz o nosso Roque Spencer de Barros, "não são a mesma coisa: a democracia implica a idéia de governo do povo, não necessariamente a idéia de liberdade do povo [...]. Podemos legitimamente falar de uma democracia totalitária", tal como 
Montesquieu, que "antecipou o quadro, melancólico e terrível, [mais tarde] pintado por Tocqueville". Não surpreende que, ao comentar a expressão "democracia liberal", ocorra-lhe dizer o seguinte: "A questão realmente substantiva não está no substantivo 'democracia', mas no adjetivo 'liberal'".

Tais temores têm a ver com o fato de que a democracia, por princípio, reclama mais do que o liberalismo pode conceder. Na perspectiva liberal, ao Estado não cabe ir além das funções ordenadoras das relações formais entre os indivíduos. Não lhe cabe assumir, tal como a democracia inevitavelmente requer, funções de configuração das esferas privadas em que se desenvolvem as atividades dos particulares, desde as econômicas até as culturais. Não é à toa que o Dicionário de Política de Bobbio e Matteucci (1986) assim se posiciona no verbete "liberalismo": "contra a concepção de democracia vista como concretização do bem comum mediante a vontade geral, ou fundamentada na exaltação da vontade da maioria, contra estas concepções monistas, o liberalismo afirma a validade do princípio pluralista".

Hayek não deixa por menos. Revelando seu desapreço pela democracia, assim se manifesta: "Se a democracia é entendida como governo conduzido pela vontade irrestrita da maioria, então não sou democrata e considero inclusive tal governo pernicioso e, a longo prazo, inexeqüível". Por trás desse descalabro estaria o positivismo jurídico, que funciona como "esteio ideológico dos poderes ilimitados da democracia".

Por todas essas passagens perpassa a insinuação malévola, infamante até, de que a democracia, se de fato não é, tende em princípio, inevitavelmente, ao despotismo. Tal seria "o curso normal do desenvolvimento da democracia". Assim, sua natureza só se revela plenamente quando ela assume a forma da democracia totalitária.

Essa expressão - "democracia totalitária" - é um oxímoro: na verdade, nada que é democrático pode ser totalitário e, vice-versa, nada que é totalitário pode ser democrático. Trata-se de uma expressão teoricamente desprovida de sentido, mas que, na prática, serve aos propósitos dos liberais, que querem preservar para si o monopólio do campo não-autocrático. Pretensão que fica evidente nesta frase de Roque Spencer de Barros (1971): “Nenhum dos tradicionais adversários do liberalismo - fascistas, comunistas, integralistas e tantos outros - 
declara-se igualmente adversário da democracia". Ou seja, o liberalismo é um herói solitário, que enfrenta sozinho adversários tenebrosos ao lado dos quais se descobre, não surpreendentemente, a indigitada figura da democracia.

Vamos e venhamos. É evidente que, ao equacionar democracia e tirania da maioria, os liberais dão um golpe baixo. Sabe-se muito bem que tirania da maioria é uma possibilidade inerente ao chamado positivismo democrático, o qual tem a ver com Rousseau e companhia - os comunitaristas de um modo geral - e não com o ideal democrático adequadamente elaborado. Os liberais autênticos, como se sabe, rejeitam a herança de Rousseau. Os democratas autênticos, com base em suas próprias razões, também não têm por que se assumirem como herdeiros de Rousseau.

Os mal-entendidos, porém, perdurarão enquanto esses mesmos democratas autênticos não se dispuserem a tomar a palavra e cumprir sua obrigação de demarcar cabalmente as diferenças que os distinguem dos liberais em geral, autênticos ou inautênticos. Enquanto esse dia não chega, a hegemonia liberal não tem o que temer. Como tantas vezes já ocorreu, pode ser obrigada a refluir ante a emergência de alguma onda autocrática, de direita ou de esquerda, mas haverá de ser restaurada, como o foi recentemente na década dos 70. Assim é porque, quando não enxergam outra alternativa, os habitantes deste lado ocidental do mundo em que vivemos preferem entregar-se ao liberalismo a ter que viver sob qualquer tipo de autocracia.

\section{CONSTITUCIONALISMO, NACIONALISMO, REPUBLICANISMO, HUMANISMO E ROMANTISMO}

Os tópicos restantes serão a seguir abordados brevemente, apenas para efeito de simples identificação ${ }^{8}$. O espaço disponível não permite mais que isso.

\section{Constitucionalismo}

Na versão dos apologistas, o liberalismo confunde-se com o constitucionalismo, como se não pudesse existir constitucionalismo fora e além do liberalismo. Isto, porém, não é verdade. Nem teórica, nem historicamente. Trata-se apenas de mais uma tentativa de monopoli- 
zação, por parte dos liberais, de tudo o que diga respeito às formas de Estado não-autocráticas.

Constitucionalismo é uma coisa: é a afirmação da necessidade (ou da imprescindibilidade) de uma carta constitucional que "desabsoluti$\mathrm{ze}^{\prime \prime}$ o poder estatal. Liberalismo é outra coisa: é a reivindicação, no interior do constitucionalismo, de um certo tipo de carta constitucional, que atende pelo nome específico de Constituição liberal.

\section{Nacionalismo}

O híbrido liberal-nacionalismo é um monstrengo cuja simples menção é suficiente para horrorizar qualquer liberal minimamente ajuizado. No passado, Roque Spencer de Barros (1971) erguia sua voz contra "os fantasmas do totalitarismo que continuam a nos sondar sob a forma do comunismo, do nacionalismo e de tantas 'terceiras posições' que de terceiras nada têm [a oferecer] além do nome". Hoje, os terceiristas que andam a propor o inaudito casamento do liberalismo com o nacionalismo deveriam ouvir a voz de Vargas Llosa, o sucessor de Spencer de Barros, que, falando em nome dos liberais de todo o mundo e de todos os tempos, não se cansa de repetir seu mote favorito: morte ao nacionalismo!

\section{Republicanismo}

Tal como Merquior, que incluía - não se sabe como - o republicanismo no "discurso teórico do liberalismo clássico", Roberto Gargarella (2000) refere-se a "autores liberais igualitários" que atualmente procuram formular "um republicanismo liberal" sobre o qual "assentam suas críticas ao liberalismo conservador". Por sorte, às vezes, o equívoco tem pernas curtas. Mesmo tendo sido capaz de escrever que o tipo de liberalismo defendido por Rawls ou Dworkin não deve ser considerado uma "opção antitética ao republicanismo", o próprio Gargarella encarrega-se de dirimir as dúvidas quando, logo adiante, mostra quão profundas, para não dizer diametralmente opostas, são "as diferenças que separam os republicanos dos liberais". Por exemplo: "O republicanismo tenta dissolver qualquer distinção drástica entre o âmbito do público e o do privado", enquanto o liberalismo "caracteriza-se pela atitude diretamente oposta". Os republicanos buscam "promover certas qualidades de caráter nos indivíduos", enquanto os liberais abominam "as interferências do Estado na moral 
privada dos indivíduos". Os republicanos cultivam "uma visão orgânica da sociedade", em que esta é compreendida como "um todo cujas partes devem conviver harmonicamente e integradas entre si", enquanto os liberais encaram os indivíduos "como seres independentes e separados entre si, [...] mais importantes do que os grupos a que possam pertencer".

E por aí prossegue o nosso autor, demonstrando, de antítese em antítese, como é impossível conjugar liberalismo com republicanismo.

\section{Humanismo e Romantismo}

De ângulos diferentes, humanismo e romantismo têm sido apresentados como dimensões integrantes do patrimônio liberal. Reencontra-se aqui o que se viu nos casos anteriores: trata-se de pretensas facetas liberais, na realidade oriundas de outras visões de mundo que não se confundem com o liberalismo. São frutos de searas alheias, indebitamente usurpadas e simplesmente carimbadas com o rótulo do liberalismo.

O nascedouro da componente humanista do liberalismo é geralmente atribuído à contribuição de Wilhelm von Humboldt, do início do século XIX. Nas palavras de Merquior (1991): "Humboldt exprimiu um tema liberal profundamente sentido: a preocupação humanista com a formação da personalidade e o aperfeiçoamento pessoal. Educar a liberdade e libertar para educar - esta era a idéia da Bildung".

Essa linha de preocupações de certa forma retoma e reconstrói as divisas do Renascimento, que lia as realizações científicas, artísticas e literárias da Antiguidade Clássica como testemunho das capacidades próprias do espírito humano e daí extraía a inspiração para incentivar tudo o que pudesse conduzir à atualização das potencialidades inerentes à vida cultural. Em suas diversas aparições históricas, o humanismo sempre envolveu a aposta na inesgotável riqueza da natureza humana e na promoção de um condizente modo de vida. É humanista quem celebra e abraça "a própria vida do espírito" (Robert, 1946) como vocação a ser cultivada.

Nada disso, como já veremos, se inclui entre os conteúdos do pensamento liberal. Essa, porém, não é a opinião de Merquior e de tantos outros adeptos do liberalismo. Para ele, "o ideal da Bildung é incrivelmente importante na história do liberalismo. Além de exercer forte 
influência em pensadores liberais que deixaram sua marca, como Constant e John Stuart Mill, ele é a estrutura lógica por trás de um conceito alemão de liberdade", o conceito "que gira em torno do desdobramento do potencial humano".

Além da tradição humanista, o liberalismo passou a reivindicar também a individualidade romântica. $\mathrm{O}$ nascedouro dessa proposição localizar-se-ia na contribuição de autores como Emerson, Henry Thoreau e Walt Whitman. O ideal do eu romântico - que os liberais passaram a exibir contra as críticas dos comunitaristas - é apresentado como aquilo que estava faltando para completar "a ambiciosa reconstrução do pensamento liberal que se iniciou na década dos 60" e culminou com "o debate centrado sobre a relação do liberalismo com a vida moral" (Rosenblum, 1993).

Segundo Rosenblum, os liberais ortodoxos (supostamente avessos ao romantismo) "não devem ter nada contra os intentos de reconstruir a teoria liberal de um modo favorável à sensibilidade romântica". A "nova onda de antiliberalismo", liderada pelos comunitaristas, tem-se beneficiado de "estar o caminho livre para que eles se apresentem como únicos portadores da concepção de uma nova moralidade e de uma nova sociedade" - depois que o pensamento de esquerda "entrou em decadência" e "perdeu seu empuxo subversivo".

Nessas circunstâncias, em que urge lançar mais uma versão revista e atualizada do liberalismo, a atitude romântica vem a calhar. Mais que outras alternativas, ela encerra "recursos potenciais" de valor inestimável para o revigoramento do secular discurso liberal. Por sorte, acrescenta Rosenblum, "uma peça-chave da doutrina - o conceito de liberdade negativa - proporciona o marco que permite a reconciliação do liberalismo com o romantismo".

É justamente por essa brecha que pretende passar a teorização de George Kateb (1993), para poder acoplar o seu romantismo (que, talvez, para facilitar, ele até chama de democrático) ao liberalismo tradicional. Por um lado, diz Kateb, "há um sentido da vida que é inerente à teoria e à prática dos direitos civis (do liberalismo clássico). É um sentido descrito em negativo. Não há uma vida boa a ser vivida, há somente vidas que não são más. Vidas insubstanciais, carentes de positividade". Para os românticos, por outro lado, "viver uma vida deve significar mais: uma vida deve ganhar uma definição; deve ser afir- 
mativa". O movimento existencial deve partir do sentimento de que, em cada indivíduo, há um potencial que ali jaz não utilizado, sufocado pelos hábitos, convenções e costumes vigentes. É preciso implodir essa crosta, deixar de se considerar "uma simples resultante de tudo o que aconteceu" e se cristalizou como forma da realidade cotidiana.

Para tanto, temos de dar vazão aos sentimentos de autoafirmação que se revelam como desejos ou, se se quiser, como retorno do reprimido. São eles: "o desejo de ser diferente, de encontrar o eu verdadeiro, desejo de viver [como atividade distinta de desempenhar um papel ou uma função], desejo de ser considerado indefinido, de ser fluído, não substancial, de acumular experiências heterogêneas, de chegar até o limite de si mesmo". Trata-se de lograr "estados do ser nos quais a preocupação com os meus próprios projetos dá lugar à preocupação com os demais", quando, por exemplo, me abro à "compreensão de tudo o que está fora de mim mesmo". Trata-se, em suma, de ser capaz de "protestos desinteressados" ou de "uma abertura poética ou filosófica para a realidade", cabendo até chegar ao ponto em que, como diz Emerson, "todo egoísmo inferior se desvanece e me transformo num globo ocular transparente; não sou nada; vejo tudo".

Humanismo e romantismo são, sem dúvida, perspectivas que têm seus encantos. Só que são encantos próprios, o acesso aos quais é vedado ao liberalismo. Isto, por várias razões. A ter que escolher a principal entre todas, fiquemos com a seguinte: humanismo e romantismo - tanto um quanto outro - são concepções que definem o sentido da vida. Por si só, isso basta para fechar a porta à entrada do liberalismo. Assim é não por causa dos defeitos do liberalismo e, sim, devido a uma de suas principais virtudes. O obstáculo que impede o liberalismo de incorporar o humanismo ou o romantismo pode ser expresso na forma da seguinte máxima: o liberalismo tolera tudo o que não seja ilegal ou imoral e não prescreve nada que tenha caráter particular. Essa é a sua regra maior, esse é o seu maior galardão.

Nenhum liberal, como indivíduo falível, está impedido de ser humanista do modo como o foram Humboldt, Constant ou Mill, ou então romântico, do modo proposto por Rosenblum e Kateb. O liberalismo, porém, como doutrina sistemática, coerentemente estruturada, não pode declarar, nem nunca declarou, qual é o sentido da vida. Isto é matéria de foro íntimo, que cada indivíduo, de forma isolada, decidirá por si mesmo, no âmbito de sua existência privada. Não cabe ao li- 
beralismo se pronunciar a favor de qual deve ser o projeto de vida ideal, não lhe compete externar suas preferências sobre a vida que deve ser vivida ou sobre as qualidades de caráter que devem ser cultivadas, nem endossar orientações valorativas - sejam elas humanistas, românticas ou quaisquer outras - que impliquem opções por objetivos e padrões de comportamento de natureza substantiva, com a conseqüente exclusão dos demais objetivos e padrões de igual natureza.

Tais vetos, é importante sublinhar, não se impõem ao liberalismo de fora para dentro. Ao contrário, decorrem do que Stephan Holmes chamou de "estrutura permanente do pensamento liberal".

Cabe lembrar, em conexão com isso, que é o utilitarismo, e não o liberalismo, que erige a utilidade em critério supremo da razão prática e sustenta a tese segundo a qual tudo na vida deve ser julgado em função da probabilidade de promover ou não o máximo de felicidade para o maior número possível de indivíduos. Foi justamente em oposição a isto que John Stuart Mill, no auge de sua profissão de fé liberal, propôs um outro princípio - a seu ver "um princípio muito simples" para reger as relações da sociedade com os indivíduos que a compõem. "Impedir danos aos outros", dizia ele, "constitui o único propósito para o qual o poder pode ser legitimamente usado, em relação a qualquer membro de uma comunidade civilizada, contra a sua vontade. O seu próprio bem, seja físico ou moral, não é justificativa suficiente" (Mill, 1946) ${ }^{9}$.

Aí se encontra, seja dito para finalizar, não só a raiz da incompatibilidade entre liberalismo e humanismo ou romantismo, mas também uma das razões de ser de sua incompatibilidade com a democracia. Do ponto de vista liberal, o complexo institucional do Estado não pode entrar em choque com as decisões das pessoas tão-somente em nome do seu próprio bem, mesmo que isso as faça mais felizes e a ninguém menos feliz. Dito de um modo mais geral, ninguém tem o direito de impor a outrem (por meio da força física ou por meio da coerção moral exercida pela opinião pública) uma concepção particular do bem. O que se pede ao Estado, como servidor da sociedade, é que zele, mediante providências para tanto adequadas, pelo ambiente em que os indivíduos (abstratamente considerados) possam desenvolver-se livremente, desde que, ao fazê-lo, não entrem em conflito com o gozo da liberdade por parte dos demais. 
Tais noções, ao mesmo tempo que são decorrências da quintessência do ideal liberal, implicam restrição de princípio à soberania popularobjetivo fundante da democracia -, a qual se materializa inevitavelmente em uma vontade dirigida à colimação de fins particulares. De que modo o exercício dessa soberania pode ser objeto de justificação teórica é algo que cabe aos pensadores democratas dizer.

(Recebido para publicação em junho de 2003)

(Versão definitiva em setembro de 2003)

\section{NOTAS}

1. Ver, a esse respeito, o instigante texto de Friedrich Hayek, "Why I Am Not a Conservative" (Hayek, 1960b).

2. Trata-se da análise desenvolvida no livro As Duas Faces do Novo, a ser publicado oportunamente.

3. Neste texto não se adota, em nenhum momento, o princípio do magister dixit para decidir se uma proposição é liberal ou não. Não se pode dizer que uma proposição é liberal simplesmente porque foi enunciada por alguém que acredita ser um liberal ou desfruta merecidamente dessa reputação. O critério aqui adotado é o da coerência lógica: é liberal toda proposição que puder ser deduzida dos postulados centrais do liberalismo. Daí a importância da reflexão, acima mencionada, sobre o que é o liberalismo como doutrina específica, sobre qual é o cerne do discurso liberal. Outra observação: a desqualificação do magister dixit implica que as citações feitas ao longo destas páginas valem apenas como ilustração - o que importa é o significado dos argumentos, não o dos autores citados.

4. Dependendo do que se enfatize - a manipulação por parte do líder ou a coonestação por parte da massa -, o cesarismo pode ser classificado tanto do lado autocrático quanto do lado não-autocrático. De qualquer modo, porém, o cesarismo distingue-se das chamadas "ditaduras simples". Nestas, o poder ditatorial é exercido por meio dos instrumentos de coerção inerentes ao desempenho das funções típicas do Estado. O caso do cesarismo é mais complexo, dado que supõe a ocorrência de apoio popular ao líder, quando não ao próprio regime ditatorial.

5. Trata-se da identificação do liberalismo com a defesa das forças de mercado. Ao que consta, "liberista" é um vocábulo inventado por Benedetto Croce para designar os adeptos do liberalismo econômico. Ao que parece, enquanto todo liberal é um liberista, não basta ser liberista para ser liberal. Se assim é, o liberista não passa de um liberal incompleto, capaz de apoiar um monarca absolutista ou uma ditadura militar, em nome do livre-câmbio e que tais. Seria uma espécie de Hobbes, no primeiro caso, ou de Roberto Campos, no segundo. 


\section{Carlos Estevam Martins}

6. Ubiratan de Macedo (1986) reage a essas propostas socializantes ao criticar a Constituição de 1946 por querer "libertar o liberalismo", sacrificando os postulados que lhe são essenciais.

7. Desta mesma obra, Legislação e Liberdade, salvo registro em contrário, procedem as citações de Hayek daqui em diante.

8. Um tratamento mais demorado desses temas encontra-se em As Duas Faces do Novo, a ser publicado.

9. Também para Kant, quando os súditos permitem que o governo julgue de que modo devem ser felizes, estamos diante do "pior despotismo que se possa imaginar".

\section{REFERÊNCIAS BIBLIOGRÁFICAS}

ANDERSON, Perry. (1989), "As Afinidades de Noberto Bobbio". Novos Estudos CEBRAP, no 24 .

BELLAMY, Richard. (1994), Liberalismo e Sociedade Moderna. São Paulo, Editora UnESP.

BOBBIO, Norberto. (1983), Qual Socialismo? Rio de Janeiro, Paz e Terra.

_. (1988), Liberalismo e Democracia. São Paulo, Brasiliense.

_. (1994), “Correspondência”. Novos Estudos CEBRAP, no 39. e MATTEUCCI, N. (1986), Dicionário de Política. Brasília, Editora Universidade de Brasília.

BONAVIDES, Paulo. (1981), "O Estado Social e a Tradição Política Liberal do Brasil”. Revista Brasileira de Estudos Políticos, noㅡㄴ. 53 .

BOSCHI, Renato. (1990), Pensamento Liberal no Brasil. Rio de Janeiro, IUPERJ.

CASTELLS, Manuel. (1999), A Era da Informação. Rio de Janeiro, Paz e Terra, vol. 2.

FARIA, José Eduardo. (1988), “Ideologia e Função do Modelo Liberal de Direito e Estado". Lua Nova, n으 14 .

FORSTHOFF, Ernest. (1973), Stato di Diritto in Transformazione. Milano, Giuffrè.

FRANCIS, Paulo. (1994), "A Voz da Heresia”. Veja, 30 de março.

GARGARELLA, Roberto. (2000), “El Republicanismo y la Filosofía Política Contemporánea". Biblioteca Virtual do CLACSO.

GRAY, John. (1988), O Liberalismo. Lisboa, Editorial Estampa.

HABERMAS, Jürgen. (1992), Morale, Diritto, Politica. Torino, Einaudi.

HAYEK, Friedrich. (1960a), The Constitution of Liberty. Chicago, University of Chicago Press. 
(1960b), "Why I Am Not a Conservative", in The Constitution of Liberty. London, Routledge.

. (1985), Direito, Legislação e Liberdade. São Paulo, Ed. Visão.

HOLMES, Stephen. (1993), The Anatomy of Antiliberalism. Harvard, Harvard University Press.

KATEB, George. (1993), “La Individualidad Democrática y el Significado de los Derechos", in N. L. Rosenblum (ed.), El Liberalismo y la Vida Moral. Buenos Aires, Nueva Visión.

LECHNER, Norbert. (1982), "El Projecto Neoconservador y la Democracia". Crítica y Utopia, no 12 .

LOCKE, John. (1998), Dois Tratados sobre o Governo. São Paulo, Martins Fontes.

MACEDO, Ubiratan de. (1986), “Os Modelos do Liberalismo no Brasil”. Revista Convivium, São Paulo.

MACPHERSON, C. B. (1962), The Political Theory of Possessive Individualism. Oxford, Oxford University Press.

MERQUIOR, José Guilherme. (1991), O Liberalismo - Antigo e Moderno. Rio de Janeiro, Editora Nova Fronteira.

MILL, John Stuart. (1946), On Liberty. London, Ed. R. B. McCallum.

RITTER, Gerhard. (1972), “El Problema Ético del Poder". Revista de Occidente, no 14, Madrid.

ROBERT, Fernand. (1946), L'Humanisme. Paris, Éditions Les Belles Lettres.

ROSENBLUM, Nancy L. (1993), “Pluralismo y Autodefensa”, in N. L. Rosenblum (ed.), El Liberalismo y la Vida Moral. Buenos Aires, Nueva Visión.

ROUANET, Sérgio. (1993), Mal-Estar da Modernidade. São Paulo, Companhia das Letras.

SPENCER DE BARROS, Roque. (1971), Introdução à Filosofia Liberal. São Paulo, Editora da USP.

THERBORN, Goran. (2000), “El Pensamiento Crítico del Siglo XX”. Encuentros XXI, noㅡ 17, Otoño del Sur, Chile.

VON MISES, Ludwing. (1977), Uma Crítica ao Intervencionismo. Rio de Janeiro, Editora Nórdica. 


\section{ABSTRACT \\ Liberalism Inside-Out}

Liberalism, as manifested in self-defined liberal writings, has two sides: one, its true side, comprised of a whole body of systematically integrated proposals; the other, a patchwork quilt, an illusionist version, manipulated for political and ideological purposes. By means of a critique of eclecticism, the article aims to provide room for acknowledging non-autocratic concepts that are treated as if they were autocratic simply because they are non-liberal or anti-liberal.

Key words: liberalism; democracy; forms of the state; self-government; autocracy; social justice

\section{RÉSUMÉ}

\section{Libéralisme: L'Endroit et l'Envers}

Le libéralisme, tel qu'on le trouve dans les textes de ceux qui se déclarent libéraux, présente deux faces: l'une, la vraie, est formée d'un corps entier de propositions systématiquement intégrées; l'autre, un habit d'Arlequin, est sa version trompeuse, manipulée à des fins idéologiques. Au moyen d'une critique de l'éclectisme, on cherche dans cet article à reconnaître des conceptions non autocratiques qui sont traitées comme si elles étaient autocratiques du fait d'être non libérales ou antilibérales.

Mots-clé: libéralisme; démocratie; formes d'État; autogouvernement; autocratie; justice sociale 